\title{
Sensitivity of platelets to aspirin in von Willebrand's disease
}

\author{
J. LESLIE ${ }^{1}$ AND D. Y. MASON ${ }^{2}$ \\ From the Department of Haematology, St Thomas' Hospital, London
}

SYNOPSIS The sensitivity of collagen-induced platelet aggregation to aspirin was measured in vitro on platelet-rich plasma from 20 normal subjects and five patients with von Willebrands disease. Although aspirin tolerance tests performed in vivo at the same time showed an abnormal prolongation of the bleeding time in three of the patients studied, no evidence was found for $\frac{\infty}{\bar{T}}$ enhanced sensitivity to aspirin in vitro.

Quick (1966) showed that aspirin increases the bleeding time in normal subjects, and this increase is accentuated in patients with various bleeding disorders (Beaumont, Willie, and Lenègre, 1955a). Weiss and Aledort (1968) showed impaired interaction between platelets and connective tissue in vivo in man after the ingestion of aspirin. This inhibitory effect has also been demonstrated in vitro by Evans (1967). If platelet aggregation induced by collagen were abnormally sensitive to the inhibitory effect of aspirin in patients with bleeding disorders, it might suggest a mechanism by which this inordinate prolongation of the bleeding time occurs. This hypothesis has been tested in the following investigation.

\section{Materials}

'Collagen' was prepared by partly homogenizing human Achilles tendon and suspending the homogenate in $0.05 \mathrm{M}$ Tris buffer, $p \mathrm{H} 7.2$, at $21^{\circ} \mathrm{C}$, with filtration through coarse nylon mesh. The suspension was centrifuged at $17,000 \mathrm{~g}$, the supernatant discarded, and the sediment resuspended in Tris. The process was repeated three times. The final suspension was stored at $-20^{\circ} \mathrm{C}$ in $0.5 \mathrm{ml}$ aliquots after rapid freezing at $-78^{\circ} \mathrm{C}$.

Received for publication 8 January 1970.

'Present address: Department of Haematology, Royal South Hants Hospital, Exmoor Road, Southampton SO2 OAS.

'Present address: Department of Haematology, Radcliffe Infirmary, Oxford.
Aspirin solutions for studies in vitro wege prepared by dissolving the powdered compour in sodium bicarbonate solution at a stoichiometrice concentration, as this was found to improze solubility. Further dilutions were made in $\mathrm{T}$ 通 buffer and solutions were stored at $4^{\circ} \mathrm{C}$ until reag for use. Solutions were discarded if not usegd within six hours of preparation.

Platelet-rich plasma was prepared by addi蒋 venous blood to $3 \cdot 2 \%$ disodium citrate solution $(9: 1 \mathrm{v} / \mathrm{v})$. After gentle mixing, specimens were centrifuged at $125 \mathrm{~g}$ for 15 minutes at $4^{\circ} \mathrm{C}$.

Polystyrene tubes and syringes were use্d throughout, and all glassware was siliconized.

\section{Subjects}

Normal subjects consisted of laboratory and medical staff, none of whom had a history of bleeding disorder. All the patients with von Willebrand's disease had a clear history (Ff haemostatic defect and affected close relatives of both sexes. In addition, each patient had on बेt least one occasion in the past been found to havea bleeding time of more than 10 minutes and factor VIII level of less than $45 \%$. Subjects wefe not tested until at least 10 days had elapsed since they last ingested aspirin. Platelet aggregation tests could not reproducibly be performed on subjects with peripheral blood platelet counts of less than $150,000 / \mathrm{cmm}$, so that these wege excluded from the study. 
Methods

BLEEDING TIME EXPERIMENTS

The effect of aspirin on the bleeding time was determined in a double-blind trial in which bleeding times on normal subjects were performed before, and two hours after, the ingestion of two gelatine-coated capsules containing either placebo (lactose) or $600 \mathrm{mg}$ aspirin. Bleeding times were performed on five patients with von Willebrand's disease after aspirin ingestion, but these patients did not receive placebo on another occasion. However, blood for platelet aggregation studies in vitro was collected from the patients immediately before base-line bleeding times were obtained. Platelet aggregation studies were also carried out one on other occasion on each patient in the group. Bleeding times were determined by applying a cuff at $40 \mathrm{~mm} \mathrm{Hg}$ to the upper arm, and making three punctures $3 \mathrm{~mm}$ deep and $1 \mathrm{~mm}$ long in quick succession in the skin of the forearm using a disposable lancet. The wounds were lightly blotted at 15-second intervals until bleeding had ceased. The mean of the three values was taken. The second bleeding time was performed on the opposite arm at the equivalent site. Punctures apparently entering veins, as shown by the blood immediately welling up, were not recorded.

\section{PLATELET AGGREGATION STUDIES}

These were carried out in the aggregometer designed by Born (1962). Platelet-rich plasma was dispensed in $0.48 \mathrm{ml}$ aliquots into a series of tubes containing magnetic stirrers covered with silicone rubber. Either Tris buffer or aspirin solution $(0.06 \mathrm{ml})$ was added to each tube and the mixtures were incubated for exactly 10 minutes at $37^{\circ} \mathrm{C}$. Then $0.06 \mathrm{ml}$ of collagen suspension was blown in and aggregation curves were recorded. For each subject, aggregation curves were obtained in response to two concentrations of collagen. At each strength of collagen, the effect of pre- $\frac{\rho}{\bar{F}}$ incubation of platelet-rich plasma with Tris buffer $\square$ and two different concentrations of aspirin was $\stackrel{0}{7}$ observed. A value for the rate of aggregation of $\frac{0}{.}$ each mixture was obtained by measuring the $\overrightarrow{\vec{F}}$ change in light transmission per unit time when aggregation was in its most rapid phase. Tests were replicated following a balanced design to eliminate the effect of spontaneous changes in the activity of reagents as discussed by Cox (1951).

\section{Results}

\section{BLEEDING TIME EXPERIMENTS}

These were performed on 10 normal subjects and $O$ six patients with von Willebrand's disease. The ingestion of $600 \mathrm{mg}$ of aspirin in normal subjects $\odot$ produced a significant mean rise in the bleeding ? time of $1.5 \mathrm{~min}$ (Table I). Placebo tablets produced $\vec{D}$ no significant difference in the bleeding time. $\mathbb{D}$ Table I also compares the effect of aspirin or $\frac{\vec{D}}{\mathbb{D}}$ placebo in normal subjects with that of aspirin in patients. As can be seen, three of the patients $\mathbb{Q}$ (nos. 1, 4, and 5) showed a response to aspirin markedly in excess of the normal range.

PLATELET AGGREGATION STUDIES

The Figure shows dose-response results obtained from a normal subject. It will be seen that the degree of inhibition was related to the concentration of aspirin in the reaction mixture. The degree of inhibition of the collagen activity may be $\overrightarrow{\vec{A}}$ calculated in such a parallel-line bioassay and 3 expressed as the 'relative collagen activity' (Table II). Values for relative collagen activity were calculated for patients and normal subjects. Table III shows increases in bleeding times in? response to aspirin beside the dose-response plots. No difference between the two groups was found, and three patients showing the greatest prolong-

\begin{tabular}{|c|c|c|c|c|c|c|c|}
\hline & \multicolumn{2}{|c|}{ Normal Subjects (10) } & \multicolumn{5}{|c|}{ von Willebrand Subjects (5) } \\
\hline & \multirow{2}{*}{$\frac{\text { Lactose }}{\text { Mean }}$} & \multirow{2}{*}{$\frac{\text { Aspirin }(600 \mathrm{mg})}{\text { Mean }}$} & \multicolumn{5}{|c|}{ Aspirin $(600 \mathrm{mg})$} \\
\hline & & & 1 & 2 & 3 & 4 & 5 \\
\hline Before & $\begin{array}{l}4 \cdot 26 \\
(2 \cdot 50-6 \cdot 25)\end{array}$ & $\begin{array}{l}4 \cdot 43 \\
(3 \cdot 41-5 \cdot 90)\end{array}$ & $11 \cdot 70$ & 8.90 & $7 \cdot 00$ & $7 \cdot 40$ & $12 \cdot 80$ \\
\hline After & $\begin{array}{l}4 \cdot 51 \\
(2 \cdot 15-7 \cdot 00)\end{array}$ & $\begin{array}{l}6.02 \\
(4 \cdot 41-8 \cdot 50)\end{array}$ & $33 \cdot 25$ & $9 \cdot 60$ & $8 \cdot 70$ & $21 \cdot 00$ & $20 \cdot 00$ \\
\hline Difference & $\begin{array}{l}+0.25 \\
(-1.00-+3.15)\end{array}$ & $\begin{array}{l}+1 \cdot 50 \\
(-0.25-+3 \cdot 30)\end{array}$ & $+21 \cdot 50$ & +0.70 & $+1 \cdot 70$ & $+13 \cdot 60$ & $+7 \cdot 20$ \\
\hline
\end{tabular}

Table I Effect of ingestion of aspirin or placebo on the Ivy bleeding time (min) in 10 normal subjects and five patients with von Willebrand's disease

The mean difference in bleeding time after placebo was not significant (SE diff $=0.429, t=0.58$, df $=18, P>0.3$ ), but the mean difference two $\mathrm{hr}$ after the ingestion of aspirin was significant (SE diff $=0.155, \mathrm{t}=10 \cdot 16, \mathrm{df}=18, \mathrm{P}<0.001$ ). The difference between the mean aspirin and the mean placebo effect, ie, the difference between the differences, was also significant (SE diff between diffs $=0.356$, $t=3.47, \mathrm{df}=36, \mathrm{P}>0.0025$ ). These SEs are derived from the pooled between-subjects variance of bleeding time results before and after placebo or aspirin in the 10 normal subjects (homogeneous by Bartlett's test: $x^{2}=3.897, \mathrm{df}=3,0.3>P>0.2$ ), with the appropriate allowances for covariance.

Differences between von Willebrand patients and normal subjects were not calculated because of the large between-subjects scatter in the von Willebrand group. 


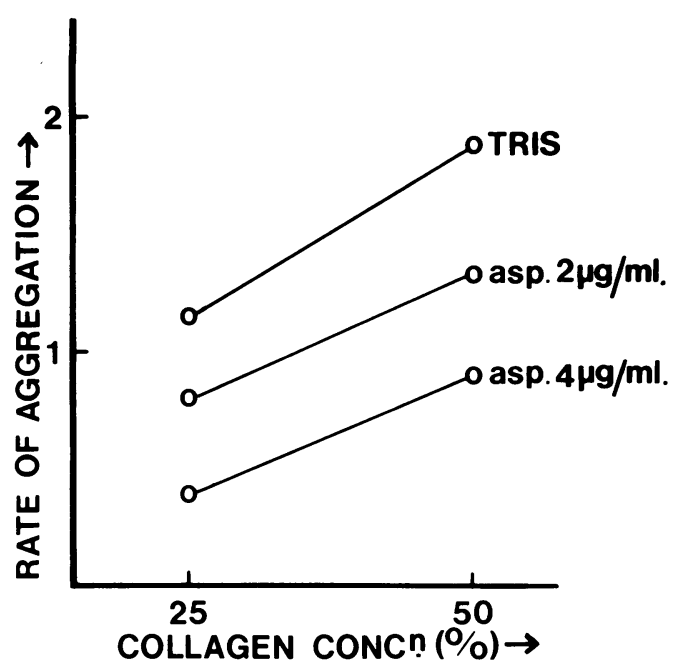

Fig. Effect of Tris buffer and two different concentrations of aspirin on the rate of aggregation of platelets using two different dilutions of an arbitrary suspension of collagen in a normal subject; aspirin concentrations are those of the reaction mixture, but collagen concentrations are those of the reagent suspension in Tris buffer. The units for the rate of platelet aggregation are arbitrary and refer to the slope of the aggregation curve in its most rapid phase. The rate of platelet aggregation is directly related to the collagen concentration and inversely to the aspirin concentration in the reaction mixture. The degree of inhibition of collagen activity may be calculated as a parallel-line bioassay to obtain 'relative collagen activity' for each concentration of collagen.

\begin{tabular}{|c|c|c|c|c|}
\hline & \multicolumn{2}{|c|}{ Aspirin Concentration } & \multirow[t]{2}{*}{ Slope Index } & \multirow[t]{2}{*}{ Position Index } \\
\hline & $2 \mu g / m l$ & $4 \mu g / m l$ & & \\
\hline & $A$ & $B$ & $A-B$ & $A \quad B$ \\
\hline Normal subjects (20) & $\begin{array}{l}0.68 \\
(0.39-0.89)\end{array}$ & $\begin{array}{l}0.47 \\
(0 \cdot 32-0 \cdot 62)\end{array}$ & $\begin{array}{l}0.21 \\
(0 \cdot 10-0 \cdot 36)\end{array}$ & $\begin{array}{l}1 \cdot 16 \\
(0.67-1.49)\end{array}$ \\
\hline $\begin{array}{l}\text { von Willebrand } \\
\text { subjects (5) }\end{array}$ & $\begin{array}{l}0.64 \\
(0.40-0.74)\end{array}$ & $\begin{array}{l}0.46 \\
(0.26-0.68)\end{array}$ & $\begin{array}{l}0 \cdot 18 \\
(0.14-0.30)\end{array}$ & $\begin{array}{l}1.00 \\
(0.66-1 \cdot 44)\end{array}$ \\
\hline
\end{tabular}

Table II Effect of aspirin on the interaction between platelets and collagen in vitro ('relative collagen activity')

The differences between the mean indices for slope or position obtained from the 'relative collagen activities' of normal subjects and von Willebrand patients were clearly not significant (for slopes, $\mathrm{SE}$ diff $=0.25, \mathrm{t}=0.24, \mathrm{df}=23, \mathrm{P}>0.5$ : for positions, $\mathrm{SE}$ diff $=0.22, \mathrm{t}=31 \cdot 8, \mathrm{df}=23, \mathrm{P}>0.5)$.

\begin{tabular}{|c|c|c|c|c|c|c|}
\hline & \multicolumn{5}{|c|}{ von Willebrand Subjects (5) } & \multirow{2}{*}{$\frac{\text { Normal Subjects (20) }}{\text { Mean }}$} \\
\hline & 1 & 2 & 3 & 4 & 5 & \\
\hline $\begin{array}{l}\text { Bleeding time increase } \\
\text { (min) }\end{array}$ & $0 \cdot 7$ & $1 \cdot 7$ & $7 \cdot 2$ & $13 \cdot 6$ & $21 \cdot 5$ & $\begin{array}{l}0.25 \\
(-1.00-+3 \cdot 15)\end{array}$ \\
\hline Slope index & 0.24 & $0 \cdot 30$ & 0.08 & 0.14 & $\begin{array}{l}0.14 \\
1.06\end{array}$ & $\begin{array}{l}0.21(0.10-0.36) \\
1.16(0.67-1.49)\end{array}$ \\
\hline Position index & $1 \cdot 24$ & 1.06 & $1 \cdot 44$ & 0.66 & 1.06 & $1 \cdot 16(0.67-1 \cdot 49)$ \\
\hline
\end{tabular}

Table III Comparison of slope and/or position index with bleeding time increase after ingestion of aspirin in von Willebrand's disease ation of bleeding time after aspirin ingestion cou传 not be distinguished from normal using either the position- or slope-indices of their dose-respons plots.

\section{Discussion}

Ashford and Freiman (1967) showed that haemostasis in small blood vessels partly involves adhesion of platelets to collagen fibres exposed the time of injury. Adenosine diphosphate (ADP is released locally by platelets (Spaet and Zucker 1964) and probably also by lysed red celds (Rorvik, Holmsen, and Stormorken, 19689. Aspirin has been shown to inhibit the release ADP by platelets (Weiss, Aledort, and Kochwd 1968) rather than the response to platelets 6 ADP, and Beaumont et al (1955b) showed this? aspirin may prolong the bleeding time in haem ${ }^{2}$ philia. Platelet aggregation in vivo might therefo로 be inhibited by aspirin, thus exaggerating an existing haemostatic defect. The present stu was carried out to determine whether the degre of inhibition of platelet aggregation in response collagen in von Willebrand's disease was great than normal. Although a platelet abnormality in this disease may have gone undetected in the design of the present experiment, the results show that in spite of an inordinate prolongation of tge bleeding time in three of the patients studied, evidence for enhanced sensitivity towards aspirêำ could be obtained in these subjects. Two of the subjects studied showed an increase in the bleedify time within the expected normal range, suggestion that a negative aspirin tolerance test is of litte diagnostic value.

We are indebted to Dr G. I. C. Ingram for ti⿱乛龰S encouragement and help in designing this study and to $\mathrm{Mr}$ J. Neuberger for his technical assis ance.

References

Ashford, T. P., and Freiman, D. G. (1967). The role of the end thelium in the initial phases of thrombosis. An elect microscopic study. Amer. J. Path., 50, 257-273.

Beaumont, J. L., Willie, A., and Lenègre, J. (1955a). Influencegुe l'acide acétyl-salicylique sur l'hémostase. Bull. Soc. mær Hôp. Paris, 71, 1077-1087.

Beaumont, J. L., Caen, J., and Bernard, J. (1955b). Act\& hémorragipare de l'acide acétyl-salicylique au cours dos maladies du sang. Bull. Soc. méd. Hôp. Paris, 71, 1087-1092.

Born, G. V. R. (1962). Aggregation of blood platelets by adenos diphosphate and its reversal. Nature (Lond.), 194,927-929.

Cox, D. R. (1951). Some systematic experimental desigs Biometrica, 38, 312-318.

Evans, G., Mustard, J. F., and Packham, M. A. (1967). Sp\&्यtaneous bruising. Lancet, 2, 724-725.

Quick, A. J. (1966). Salicylates and bleeding: the aspirin tolerane test. Amer. J. med. Sci., 252, 265-269.

Rorvik, T. O., Holmsen, I., and Stormorken, H. (1968). The release of ADP from red blood cells. Thrombos. Diaths. haemorrh. (Stuttg.), 19, 77-83.

Spaet, T. H., and Zucker, M. B. (1964). Mechanism of platêfet plug formation and role of adenosine diphosphate. Aper. J. Physiol., 206, 1267-1274.

Weiss, H. J., Aledort, L. M., and Kochwa, S. (1968). The efect of salicylates on the hemostatic properties of platefts in man. J. clin. Invest., 47, 2169-2180. 